\title{
Strategies for Chinese Engineering Enterprises in International Publicity from the Perspective of Domesticating Translation—C Case Study of CRCC
}

\section{Fang Shu ${ }^{1}$ Shan Huang ${ }^{2,3 *}$}

1. The School of Foreign Languages of East China Jiaotong University, Nanchang, Jiangxi, 330013, China

2. The School of Foreign Languages of East China Jiaotong University, Nanchang, Jiangxi, 330013, China

3. The Faculty of Social Sciences, University of Macau, Macau, 999078, China

\begin{tabular}{l} 
ARTICLE INFO \\
\hline Article history \\
Received: 17 September 2020 \\
Revised: 24 September 2020 \\
Accepted: 9 October 2020 \\
Published Online: 16 October 2020 \\
\hline
\end{tabular}

Keywords:

Domesticating translation

Chinese engineering enterprises

International publicity translation

\section{Introduction}

$\mathrm{I}$ $n$ recent years, the overseas markets of Chinese enterprises have been expanding and China's international influence has been increasing, while the scale of Chinese enterprises' foreign contracting projects has also expanded especially after the introduction and implementation of the Belt and Road Initiative. According to statistics from the Ministry of Commerce, China's foreign contracting engineering business completed a turnover of $\$ 172.9$ billion in 2019, up 2.3 percent year-on-year, with new contracts worth $\$ 260.25$ billion, up 7.6 percent yearon-year $^{\mathbb{D}}$. From this statistic, it is obvious that the expansion of overseas markets of Chinese engineering enter-

(1) 1.http://data.mofcom.gov.cn/tzhz/forengineerstac.shtml

\section{ABSTRACT}

With the expanding overseas markets to Chinese enterprises, the international publicity has showed its significance. A high-quality translation helps to shape an outstanding international image and boost the international publicity, vice versa. This paper studies the case of CRCC to analyze and explore the translation strategy from domesticating translation perspective, aiming to offer some insights to Chinese engineering enterprises in their international publicity promotion. prises is the trend, thus to better expand overseas markets, the international publicity work of engineering enterprises becomes particularly important.

As it is known, the translation of corporate international publicity materials can serve the enterprise's economic development and market development well, as well as for the benefit of its scientific and technological progress and foreign exchange and cooperation. Through the international publicity translation, the international competitiveness of the enterprise will be improved continuously. In addition, the international publicity translation can build a bridge for the enterprise to enter the international market, not only by publicizing the enterprise's excellent projects, products and business development advantages, but also effectively for the purpose of enhancing the enterprise's

*Corresponding Author:

Shan Huang,

The School of Foreign Languages of East China Jiaotong University, Nanchang, Jiangxi 330013, China;

The Faculty of Social Sciences, University of Macau, Macau, 999078, China;

E-mail:yc07332@umac.mo. 
international reputation (Tang Linnan. 2012: 4). As most of the overseas communications of engineering enterprises are conducted in English, corporate international publicity materials are the first-hand information for potential overseas customers to understand the company, so the quality of the English translation has a profound influence on the shaping of corporate image.

Therefore, this paper studies the case of China Railway Construction Corporation (CRCC) to analyze and explore the translation strategy from domesticating translation perspective.

\section{Theoretical Basis}

\subsection{International Publicity Translation}

"Corporate International Publicity Translation" refers to inter-language translation activities for corporate international publicity materials, the purpose of which is to publicize corporate information, products or services of the enterprise to overseas target language readers, to build a fine image of the enterprise overseas, to sell products or services produced by the enterprise to overseas customers, to realize the enterprise's benefits economically and socially(Xu Jun, Zi Zhengquan. 2020: 94).

\subsection{Domesticating Translation}

Domestication was proposed by Venuti in his book The Translator's Invisibility in 1995. According to Venuti, domestication is "an ethnocentric reduction of the foreign text to target-language cultural values, bring the author back home". In other words, domestication requires the translator to move closer to the target language readers and adopt the expressions used by the target language readers to convey the original content (Feng Qinghua, Chen Kefang. 2019: 10).

Since the purpose of corporate publicity is to better publicize its image, arouse overseas customers' interest in cooperation, and ultimately promote economic and social development, it is better to adopt the expressions used by overseas customers to promote the enterprise in the translation process of its publicity materials. If there are cultural differences and conflicts, the translator can, on the basis of respecting the main information in the original text, adopt a flexible and appropriate translation method according to the translation requirements and objectives, so as to eliminate cultural information rejection and conflicts, and narrow the psychological distance, to gain the psychological recognition of the readers and clear away the obstacles for the target language readers to accept the translation. (Zhang Xiaojing, Wang Yijiang. 2011: 118) Therefore, it is of great benefit to try to apply domesti- cation translation strategy to the translation of publicity materials of engineering enterprises.

\section{Specific Analysis}

Most of the corporate publicity materials are translated into English word by word, which seems to be faithful to the original text, but in fact they might ignore the cultural differences between China and the West, causing poor publicity effect. As one of the "Fortune Global 500", China Railway Construction Corporation Limited (CRCC) embodies certain analytical value in its English translation of publicity materials. After comparing the official Chinese and English website versions of China Railway Construction Corporation Limited, it can be seen that although most of the company's publicity materials are translated word by word, there are still translation methods that can be used as reference.

Example 1: The Chinese and English website sections of China Railway Construction Corporation Limited are different. In the Chinese version, 13 sections are set up: “首页” “企业概况” “新闻中心” “党建及群团工作” “主营业务” “科技创新” “海外业务” “法律合规” “人 力资源” “社会责任” “企业文化” “投资者关系” and “信息公开”. However, in the English website, there are only seven sections: "Home", "Profile", "News", "Business", "Overseas", "Investor" and "CSR".

By comparing the setting of the company's Chinese and English website sections, the author found that, compared with the allocation of the Chinese website sections, the allocation of the English website sections is more concise, and the details of “党建及群团工作” and “法 律合规" with Chinese characteristics are not reflected in the English website. This is a domestication translation process after considering the cultural differences between China and the West, concise and clear, which is more convenient for readers to obtain the required information.

Example 2: In the Company Profile section of the website of China Railway Construction Corporation Limited, the Chinese text introduces the company's awards, such as “累计获国家科学技术奖 81 项，国家级勘察设计 咨询奖 154 项，詹天佑土木工程大奖 101 项，国家优 质工程奖 394 项，中国建筑工程鲁班奖 142 项; 累计 拥有专利 14023 项，省部级以上工法 3270 项”巴, but after careful comparison of the English translation of this section, it is found that the English version has no such corresponding translation.

The author believes that this is because most of the time, overseas readers are not aware of the Chinese awards, and even if the names of these awards are trans-

(1) http://www.crcc.cn/col/col1569/index.html<2020-08-06> 
lated, there seems to be no comparative meaning. If they were translated one by one, it would affect the reading experience of the readers, and would not help with improving the image of the company. Therefore, companies tend to adopt a naturalization strategy and select key points for translation.

In addition, in the Business section of the website of China Railway Construction Company Limited, there is a big difference between the English and Chinese publicity materials introduced in the Equipment Manufacturing section. Obviously, the Chinese materials focus more on reflecting the morale of the enterprise, while the English materials focus more on reflecting factual information, such as the distribution of the production bases and the main business of the enterprise, as shown in Example 3 and Example 4.

Example 3: The Chinese material ends with “中国铁 建愿秉承' 诚信、创新永恒，精品、人品同在' 的企 业价值观，与社会各界朋友精诚合作，互利共赢，共 同促进我国装备制造行业发展，为建设和谐社会做 出更大的贡献! " with a brief introduction of China Railway Construction Heavy Industry Corporation Limited (CRCHI), a subsidiary of China Railway Construction Corporation Limited.

Example 4: The English starts with, "The production bases of CRCC Industry Plate are distributed in Beijing, Kunming, Changsha, Xi'an, Lanzhou, Urumqi, Changzhou, Wuxi and other regional core cities. The main business covers large railway track maintenance machinery, track construction equipment, tunnel boring machine, special construction equipment and electrified components and other industries. Its products are mainly for railway and urban rail transit new and existing railway reconstruction projects." (2) It introduces the distribution of the production bases, main business and the use of products of China Railway Construction Corporation Limited. The first paragraph of the Chinese version, however, gives a brief overview of the company with the sentence: “中国 铁建是集研发、制造、销售、服务为一体的国内领先、 国际先进的施工装备制造商”, and the whole article does not mention substantive information such as the distribution of the production bases.

The reason why it introduces like this is because of the different language styles between China and the rest of the world. The Chinese language is characterized by the fact that it is both virtual and real, and the wording in the articles on the websites of Chinese companies is exagger-

\footnotetext{
(1) http://www.crcc.cn/col/col1596/index.html<2020-08-06>

(2) http://english.crcc.cn/col/col21590/index.html<2020-08-06>

(3) http://www.crcc.cn/col/col1596/index.html<2020-08-06>
}

ated to some extent, while the language on the websites of overseas companies is more objective and stable, and it speaks in terms of facts and data, with detailed information to achieve the purpose of publicity and marketing (Liu Ying. 2011: 66). Therefore, adopting domestication strategy in publicity translation is better for companies to attract overseas customers.

\section{Conclusion}

The enterprise web page is essentially the electronic version of the enterprise's "resume" and is a powerful tool for the enterprise to publicize itself. (Wang Junchao. 2019: 62) Therefore, to do a more impressive job in English publicity of enterprises, it is necessary to fully consider the needs of the target language readers and then select appropriate translation strategies. However, through a brief analysis of the Chinese and English websites of China Railway Construction Corporation, we can understand that domestication strategy is very effective in translating similar texts. During translation, attentions should be paid more to the social function and purpose of the publicity translation, which is to publicize and carry forward the Chinese culture to the target language readers (Yuan Sen, Miao Yu. 2020: 23), and also to better reflect the advantageous image of the enterprise. Therefore, when doing a high quality job in the publicity translation of Chinese engineering enterprises, it is suggested to adopt the target language reader-centered domestication translation strategy.

\section{Acknowledgments}

Fund: This paper is a research result of an empirical study on the Correlation between the Self-efficacy of Engineering Interpreters and their Translation Effectiveness (Serial Number: JD18102), a key research base of Humanities and Social Sciences in Universities of Jiangxi Province, and also a project result of Thematic Interpretation Course (Serial Number: 1102019004), a case study for graduate students in Jiangxi Province.

\section{References}

[1] Feng Qinghua, Chen Kefang. An Elementary Coursebook on Chinese-English Translation [M]. Beijing: Higher Education Press, 2019.

[2] Liu Ying. Analysis of Applicable Principles and Unique Methods of Enterprise Website Translation [J]. Practice in Foreign Economic Relations and Trade, 2011(01): 66-68

[3] Tang Linnan. The Principle, Strategy and Method of Chinese-English Enterprise Publicity Material Trans- 
lation [D]. Central China Normal University, 2012.

[4] Wang Junchao. Constructing the Research Framework of Chinese Enterprises" "Go Globally" International Publicity Translation [J]. Shanghai Journal of Translators, 2019(02): 62-66.

[5] Xu Jun, Zi Zhengquan. A Corpus-based Study on Corporate International Publicity Translation and Semantic Construction of Corporate Image [J]. Foreign Language Research, 2020(01): 93-101.

[6] Yuan Sen, Miao Yu. An Investigation and Study on Xi'an's International Publicity Materials under the Background of "the Belt and Road Initiative" from the Perspective of Translation Aesthetics [J]. Journalism Knowledge, 2020(05): 23-27.

[7] Zhang Xiaojing, Wang Yijiang. Translator's Subjectivity in Company Profiles Translation [J]. Journal of
Hebei Polytechnic University (Social Science Edition), 2011(04): 117-119.

[8] China Railway Construction Corporation Limited. Equipment Manufacturing. URL:http://english.crcc. $\mathrm{cn} / \mathrm{col} / \mathrm{col} 21590 /$ index.html<2020-08-06>

[9] Ministry of Commerce. Statistics of Foreign Contracting Engineering Business. URL:http:// data.mofcom.gov.cn/tzhz/forengineerstac.sht$\mathrm{ml}<2020-08-17>$.

[10] China Railway Construction Corporation Limited. Company Profile. URL: http://www.crcc.cn/col/col1569/index.html $<2020$ 08-06>.

[11] China Railway Construction Corporation Limited. Equipment Manufacturing. URL:http://www.crcc.cn/ $\mathrm{col} /$ col1596/index.html<2020-08-06>. 